\title{
ACTIVATING METHODS IN TECHNICAL EDUCATION
}

\section{Jan NOVOTNÝ}

\author{
AKTIVIZUJÍCÍ METODY V TECHNICKÉM VZDĚLÁVÁNÍ \\ (ZUKERSTEIN, J. Aktivizujíci metody v technickém vzdělávání. 1. vydání. Ústí nad Labem: \\ Univerzita J. E. Purkyně, 2012. 112 s. ISBN 978-80-7414-430-1.)
}

V roce 2012 přichází Univerzita Jana Evangelisty Purkyně v Ústí nad Labem s publikací Aktivizující metody $\mathrm{v}$ technickém vzdělávání autora PhDr. Jaroslava Zukersteina, Ph.D. Uvedená monografie je vydána $v$ souvislosti s projektem „To je věda, seznamte se“ podpora systematické práce $\mathrm{s}$ žáky a studenty $\mathrm{v}$ oblasti vědy, výzkumu a vývoje CZ.1.07/2.3.00/09.0121 který je spolufinancován Evropským sociálním fondem a státním rozpočtem České republiky.

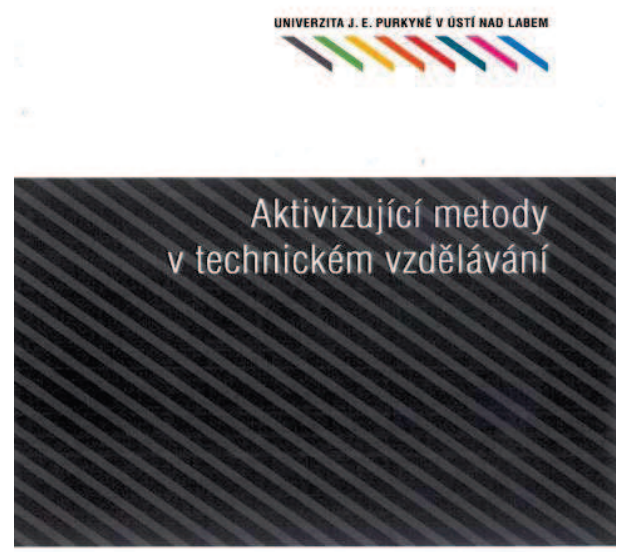

Jaroslav Zukerstein

Autor se ve své práci zabývá využitím metod aktivizujících žáky $\mathrm{v}$ technickém vzdělávání. Cílem práce je předložit východiska předpokládající využití těchto metod jako prostředku pro efektivnější technické vzdělávání, hlavním cílem je pak prostřednictvím výzkumných nástrojů ověrit, že aktivizující metody $\mathrm{v}$ technickém vzdělávání jsou prostředkem pro efektivnějšś a trvalejší získávání poznatků a dále pak, že tyto metody zvyšují oblíbenost předmětu a ovlivňují postoj $\mathrm{k}$ tomuto předmětu a vlastnímu vyučovacímu procesu.

Monografie je rozdělena do dvou hlavních částí, v té první autor klasifikuje vyučovací metody $\mathrm{v}$ souvislosti $\mathrm{s}$ aktivizujícím pojetím, zaměřuje se na technické vzdělávání ve vztahu k těmto metodám. Druhá, výzkumná část práce je zaměřena na využivání aktivizujících metod při technickém vzdělávání $\mathrm{v}$ rámci předmětu „praktické činnosti“ na druhém stupni ZŠ. Hlavními dvěma oblastmi pozornosti jsou oblíbenost vyučovacího předmětu u žáků ve vztahu $\mathrm{k}$ zařazování aktivizujících metod a dále efektivita a trvalost získávání poznatků při využivání aktivizujících metod.

Práce ověřje stanovené hypotézy prostřednictvím výzkumných aktivit provedených na druhém stupni základních škol $\mathrm{v}$ rámci předmětu praktické činnosti a prezentuje dosažené výsledky. Cílem výzkumné části práce je oveřit, že vhodné zařazování a využívání aktivizujících metod $\mathrm{v}$ oblasti technického vzdělávání má vliv na oblíbenost a postoj žáků $\mathrm{k}$ vyučovacímu předmětu a vede $\mathrm{k}$ efektivnějšímu a trvalejšímu získávání poznatků.

Jako velmi př́nosný spatřuji návrh a organizaci pedagogického experimentu ve vztahu $\mathrm{k}$ hypotézám, vytvoření nástrojů experimentu v podobě dotazníku a testů, zařazení testových položek dle Niemierkovy taxonomie výukových cílů postihujících kategorie osvojení učiva.

Publikaci lze chápat jako velmi vyvážené pojetí uvedené problematiky, která je podložena nápaditě a pečlivě zpracovanou výzkumnou částí. Zvláště bych vyzdvihl vytvoření podkladů a př́íprav pro vyučovací hodiny v experimentálních skupinách, které by mohly být inspirací pro práci učitelů technické výchovy

PhDr. Jan Novotný, Ph.D.

Katedra matematiky a fyziky

Fakulta výrobních technologií a managementu

Univerzity J. E. Purkyně

Na Okraji 1001, Ústí nad Labem, ČR

Tel: +420 475285511

E-mail: novotny@fvtm.ujep.cz

Www pracoviště: www.fvtm.ujep.cz 